\title{
Research and Educational Centers as a Matrix of Institutional Collaboration Between Business, Science, and Education in the Context of Digital Transformation in Society
}

\author{
K.A. Markelov ${ }^{1}$ E.V. Polyanskaya ${ }^{1}$ O.K. Mineva ${ }^{1, *}$ A.M. Abbasov ${ }^{2}$ \\ ${ }^{1}$ Astrakhan State University, 20A Tatishchev Street, 414056 Astrakhan, Russia \\ ${ }^{2}$ Azerbaijan National Academy of Sciences, 30, Istiglaliyyat str.,Baku Az1001, Azerbaijan \\ *Corresponding author. Email: okmineva@ rambler.ru
}

\begin{abstract}
The global economic and social changes prompted by digital transformation are a comprehensive process that alters both the structure and image of traditional goods and services markets. As the digital paradigm has been seeing enormously rapid changes, and since emerging digital jobs have not been assigned with sustainable requirements and definitive skills set as of yet, there is a pressing need to introduce new forms of interaction between economic agents. More specifically, cooperation today is able to stand in as the organizational form to fully cater to the requirements of economical digitalization, globalization and comprehensive economical integration, it can "blend" national and faith-based features with the new forms of online and offline education. The article shows the efficiency of Research and Education Center (RECs), them being a matrix of institutional collaboration between business, science and education set against the backdrop of digital transformation in society.
\end{abstract}

Keywords: Research and Education Center (REC), cross-institutional collaboration, digital economy, science, education, business, economic agents

\section{INTRODUCTION}

Natural development of institutional institutions by incorporating collaborative forms of interaction between economic agents

Since few decades, every single national economy has been navigating out of the industrial economy paradigm towards the digital-based one. This fact contributes to the revolutionary new collaborative forms of interaction between all the economic agents. The collaborative nature of production management stems from that the knowledge component has been increasing significantly. Institutional thought links the paradigm shift in regards of traditional economic agents' interaction to having more collaborationtype transactions (clusters, consortia, conglamerates, holdings, etc.).

Modern collaborative forms of interaction are based on the principle of mutuality that is called reciprocity and opposed to the traditional equal exchange of benefits between economic agents that leans towards using mechanisms of social evaluation (such as considering the overall image of economic agents, social responsibility, etc.).
Collaborative forms of interaction today are not opposed to the institutional ones, naturally limited by their structural rigidity (predetermined by the initial creation basis). With digital economy, mobile collaborative forms of interaction are "new blood", rejuvenating the body (which are institutional formations and institutions).

\subsection{The mechanics behind collaborative interaction between education, science and business}

Many modern researchers, such as Angelini, P., Belberdos, R., Lokshin B. [1], Wang, C.-H., Syen, G.S.[2], Davern, M. [3], White, H. [4], Vasilenko, N.V.[5], Yakunaeva, S.G. [6], focus on particularly how collaboration in science and education works.

The specific attribute of collaborative forms in science and education is the creative (rather than distributive) goal which implies creating a new intellectual product (a technology, a finished prototype, a new educational program, educational technologies).

Collaborative forms of interaction rely on trust, mutual respect and understanding the right to freedom of opinion. This "science-education-business" triple interaction marks 
them out from traditional hierarchical institutional institutions that rely upon status-based subordination of the economic actors. At the same time, it is trust and openness, the absence of coercion that contributes to the long-term interaction between the participants as this basis provides for new but more flexible institutional groups (consortia, clusters, etc.) wielding a more mobile nature.

It is collaboration that provides a means of educating specialists of the future (education), so that they can work in the industries of high uncertainty and risk (science \& business) with their hard and soft skills having been wellshaped at the very start of their professional way. This will yield a multiplicative effect significantly relieving the turbulence outside for all the economic agents - for all those who participate in said collaboration.

\subsection{The authors' view at matrix formation}

In Figure 1, the authors present how they view a modern matrix of institutional collaboration between business, science and education against the backdrop of digital transformation in society.

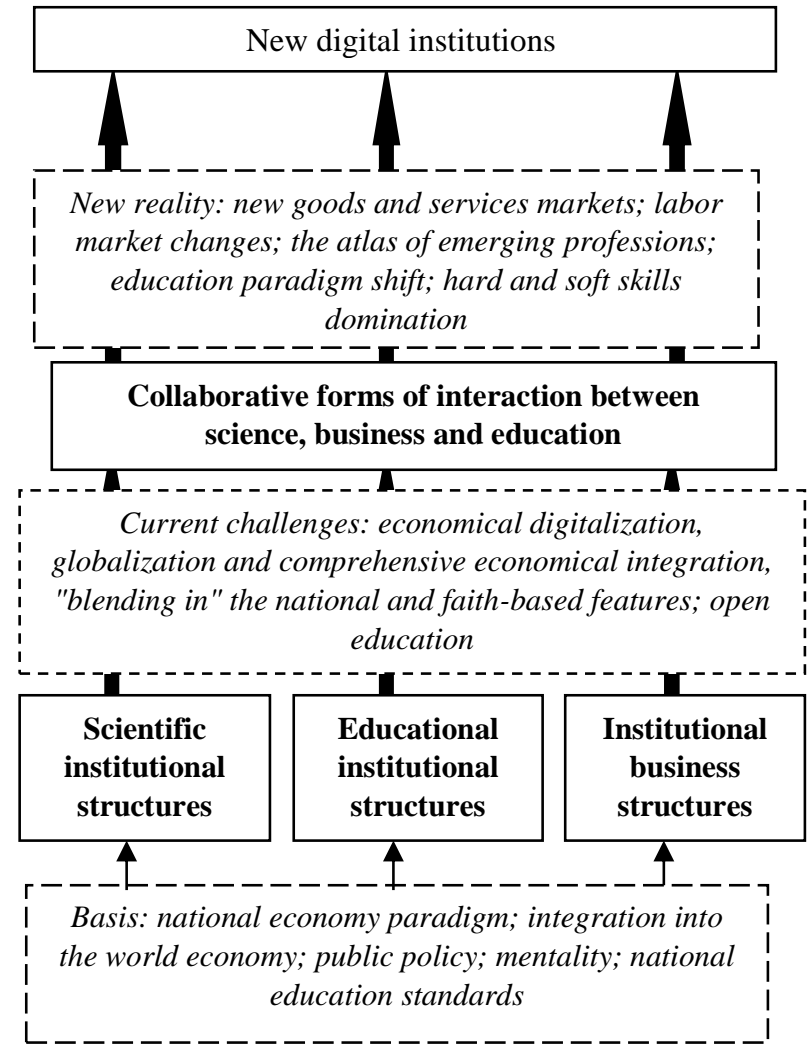

Figure 1 Modern view at the matrix of institutional collaboration between business, science and education against the backdrop of digital transformation in society

\subsubsection{Traditional institutional structures and the irpreconditions}

First of all, the basic installations of traditional institutional structures were connected to the national economy paradigm, its integration into the world economy, its public policy characteristics in the scientific, educational and production field, the country's mentality and the open or closed nature of the state education standards. The industrial economy paradigm implied a clear hierarchy of all social processes with the economic agents building their relationships on equal exchange of benefits. At the heart of all relationships was the maximization of profit per unit of physical or monetary capital. Time lag of technological paradigm changes (Kondratieff Waves) proved to have had a significant duration (up to 50 years), which has allowed for a smooth reinventing of educational programs, techniques and technologies.

\subsubsection{The economic agents' interaction paradigm change}

Since mid-20th century, as scientific and technological progress was gaining momentum, the cycles have been experiencing a gradually compression by $10-15$ years in average. The assumption is that the sixth economic cycle (approx. 2015 - 2035) will be shorter than such of the 19th century by roughly 2.5 times. It should be noted that earlier in time it were the assets that often failed to keep up with the technical innovations. Nowadays the society changes in the light of the disruption technologies. As the digital paradigm has been seeing enormously rapid changes, and since emerging digital jobs have not been assigned with sustainable requirements and definitive skills set as of yet, there is a pressing need to introduce new forms of interaction between economic agents. In particular, cooperation today can become an organizational form that will offer the possibility to fully take the requirements of the economy digitalization, globalization and integration of all economic processes into account, "blending in" the national and faith-based features and new forms of online and offline education.

\subsubsection{Building new institutional structures through $\underline{\text { collaboration }}$}

The digitalization mechanisms embrace the whole globe meaning the crucial transformations occur simultaneously in all sectors of the economy. Digital reality, intangible assets overrunning the tangible ones by several times, an extremely short term of monetary return on know-how investments, changing education paradigm, prevailing of hard and soft skills over traditional professional ones have resulted in a remarkable transformation of the institutional institutions. At the same time, the most significant changes for the whole world (from a social point of view) are the ones in national and global labor markets. The modern labor market is characterized by: 
- Robotization of production processes that leads to less employment in the production field all while the number of employees in the service sector is growing. However, those are temporary processes. Soon the artificial intelligence will also permeate the service sector, too, so the number of human jobs will reduce);

- Total digitalization that erases the boundaries of national and global labor markets, invigorating globalization and hastening the remote work practices;

- A significant cutback in some "traditional" professions (up to their complete disappearance), new ones emerging (many of such have not been described in terms of their functions meaning there are no educational standards for them yet.). According to Frey, K. and Osborne, M., due to the severe robotization the United States will lose more than $47 \%$ of jobs (of all available in 2018) by 2033, in Germany this rate will be $35 \%$, in Japan - $21 \%$, Russia - up to $30 \%$. According to the World Bank, in China this rate can amass $77 \%$ by 2033 [7].

-The groundbreaking changes in qualification requirements, skills required in most "traditional" professions which really transforms the very essence of employment.

All this evokes emergence of new institutional structures based on a formal rather than rigid hierarchy, which collaborative processes rest on the principle of equality and trust shared by all the participants.

\section{BACKGROUND}

\subsection{What factors into creating Research and Educational Centers (REC) and what advantages the participants have}

Research and Educational Centers represent a relatively new form of collaborative cooperation in the field of business, science and education. In accordance with the Presidential Executive Order No. 204 dated May 7, 2018 "On National Goals and Strategic Objectives of the Russian Federation through to 2024" [8], the state aims at creating at least 15 world-class Research and Educational Centers for the universities and scientific organizations to cooperate with the real sector organizations.

Pursuant to this Order, the "Science" national project has been approved which defines the primary tools and parameters to establish Research and Educational Centers. Also, a Decree of the Russian Federation Government dated 30.04.2019 No.537 "On measures of the state support of world-class scientific and educational centers based on the integration of educational institutions of higher education and scientific organizations and their cooperation with organizations operating in the real economy" was adopted [9].

According to this Decree, Perm Krai, Belgorod, Kemerovo, Nizhny Novgorod and Tyumen Oblasts were determined (on a non-competitive basis) as having the world-class RECs in 2019. To date, circa 40 more RECs have been organized in various regions of the Russian Federation. According to the
Ministry of Education and Science of Russia, a REC can be called a "technological web" of a country, designed to ensure the territorial cohesion in order for the regions to develop intellectually, technologically, economically, etc. In other words, it is a tool the scientific staff uses to move across the country, it also retains said staff and capacities in the regions to avoid their overconcentration in Moscow and St. Petersburg. Another aim of RECs is its very essence as a REC is a "magnet for minds". It is about ensuring the appropriate conditions to train the scientific staff for the region's educational and economic needs. Such "magnet" is the result of collaboration between the regions and their industrial partners. The aim is to create comfortable environment at where a REC is located while featuring the universities and the REC participants who practically reboot the regional economic sectors.

The collaborative essence of a REC is the network interaction of all country's RECs resulting in reinforcing and complementary effects.

The REC participants benefit from new opportunities and various advantages:

- from taking part in the comprehensive scientific and technical program of a full innovation cycle to considering the REC status in case of the state accreditation and higher education monitoring;

- developing and implementation of the Comprehensive Research and Engineering Programs;

- ensuring legal protection of the rights to intellectual property and protection of both received and transferred to be managed ones, including abroad;

- commercialization of the Intellectual Property obtained, including market research, and finding partners to promote products to specific markets, including external ones;

- implementation of educational activities by the Program initiator and participants of the REC, educational activities in the field of higher education - the undergraduate and postgraduate studies;

- targetedhighereducation outreach;

\subsection{The "Kaspii" REC: mission, idea, participants, expected effects}

The "Kaspii" REC rests on five elements the Ministry of Education and Science views as crucial when considering the REC applications:

-World level education, research and educational activities relevance;

- Integration into the national economic agenda (including integration into the national projects), interregional links;Regional instruments and programs engagement, attractiveness of investment environment or depth of business strategy;

- Greater impact the REC Program can have on the economy, demography, the region's "magnetism";

- International cooperation level.

Contribution to the regions' scientific, technological and educational development, the "Kaspii" REC includes 
can turn businesses towards innovative technical and technological development, which would not have been possible when preserving traditional hierarchical institutional structures. The "Kaspii" REC demonstrates that the key indicators of the project prove to be efficient and attainable. This benefits not only the participants of this association, but also our society and state.

\section{REFERENCES}

[1] Belderbos R., Carree M., Lokshin B., Intertemporal patterns of $R \& D$ collaboration and innovative performance, The Journal of Technology Transfer, 2015,vol. 40, no. 1,pp. 123-137.

[2] Wang C.-H., Chang C.-H., Shen G.C., The effect ofinbound open innovation on firm performance: evidence from high-tech industry, Technological Forecasting and Social Change, 2015, vol. 99, pp. 222-230.

[3] Davern M., Social Networks and Economic Sociology: A Proposed Research Agenda For a More Complete Social Science, American Journal of Economics and Sociology, 2017, Volume 56. №3. P. $287-302$.

[4] White H. Where Do Markets Come from?, American Journal of Sociology. 2011. Volume 87. P. $517-547$

[5] Vasilenko, N.V. Institutsionalnye osobennosti kollaboratsii $\mathrm{v}$ organizatsionnyh strukturah innovatsionnoi ekonomiki, Nauchno - tekhnicheskie vesti [Institutional features of collaboration in organizational structures of innovation economics] SPbSPU. 2016. 4 (246). p. 21-28.

[6] Iakunaeva S.G., Koshurnikova Iu.E. Doverie i klientoorientirovannost' kak faktory uspekha firmy. Fundamental'nyeissledovaniia, 2013, № 6-4. S.971- 975 .

[7] Kak roboty zameniat liudei [How robots will replace humans]// http://www.tadviser.ru [Internet source]. URL:

www.tadviser.ru/index.php/\%D0\%A1\%D1\%82\%D0 $\%$ B0\%D1\%82\%D1\%8C\%D1\%8F:\%D0\%9A\%D0\% B0\%D0\%BA \%D1\%80\%D0\%BE\%D0\%B1\%D0\%B E\%D1\%82\%D1\%8B \%D0\%B7\%D0\%B0\%D0\%BC \%D0\%B5\%D0\%BD\%D1\%8F\%D1\%8E\%D1\%82\% D0\%BB\%D1\%8E\%D0\%B4\%D0\%B5\%D0\%B9.

(Date of access: 20.01.2020).

[8] Ukaz Prezidenta RF ot 7 maia 2018 goda № 204 "O natsionalnyh tseliah i strategicheskih zadachah razvitiia Rossiiskoi Federatsii na period do 2024 goda" [Presidential Executive Order 
No. 204 dated May 7, 2018 "On National Goals and Strategic Objectives of the Russian

Federation through to 2024"]

[9] Postanovlenie Pravitelstva RF ot 30.04.2019 №

537 "O merah gosudarstvennoi podderzhki nauchnoobrazovatelnyh organizatsii vysshego obrazovaniia i nauchnyh organizatsii i ih kooperatsii s

organizatsiiami, deistvuiushchimi v realnom sektore ekonomiki." [Decree of the Russian Federation

Government dated 30.04.2019 No.537 "On measures of the state support of world-class scientific and educational centers based on the integration of educational institutions of higher education and scientific organizations and their cooperation with organizations operating in the real economy."] 